\title{
Universities' Role in Addressing Terrorism in Light of Students' Awareness to its Definition, Causes, and Types
}

\author{
Dr. Reem Al Zou'bi \\ Al al- Bayt University, Jordan \\ doi: 10.19044/esj.2017.v13n13p253 URL:http://dx.doi.org/10.19044/esj.2017.v13n13p253
}

\begin{abstract}
The study aims to explore the degree of awareness of Jordanian education college students to terrorism's definition, type and causes, and the universities' roles in addressing terrorism. A five- scale questionnaire was designed by the author and administrated to 130 students studying at the faculty of education, Al-al Bayt University. The external reliability coefficient for the total questionnaire domains was 0.84, and the internal reliability coefficient (Cronbach Alpha) for the total questionnaire domains was 0.88 . This indicates that the questionnaire was reliable and suitable for a sample administration. The results indicated that students were aware of the concept and types of terrorism, but they have a misconception of its main causes. These, however, were relevant from the perspectives of economical and social causes. Students' misconception can be interpreted by students' social alienation, and their refusal based on economic and social circumstances. The author suggested that universities must hold intense rehabilitating programs for the youths. This is in addition to holding international conferences on human security as it could raise students' awareness of terrorism and help them in addressing it eventually.
\end{abstract}

Keywords: Terrorism, Education College students, Al-al Bayt University

\section{Introduction \& Background of the Study}

Terrorism, as a phenomenon, is threatening due to the absence of social security and the ease of smuggling arms and bringing them to the hands of those who think of killing and terrorizing innocent individuals as an inevitable means to achieve their goals. As a result, the governments of many countries are forced to face a great difficulty in uprooting this phenomenon and finding radical solutions to it.

Terrorism is not only a product of perverse ideology, but is also the product of a more perverse reality. In fact, delinquent reality generates 
terrorism in the level of intellect and practice. Our societies are filled with terrorism generators which are apparent in the absence of justice, democracy, and human rights.

In the last few decades, there has been an emergence of radical religious political movements, sometimes of a terrorist nature in the Middle East (Dalacoura, 2006). Jordan, for instance, from 1991 until 2005 has witnessed small violent terror acts attributed to Islamic groups that seem to appear and disappear constantly. Thus, this was after having their members was arrested and their organizations were dismantled. Subsequently, those organizations were targeting the U.S embassies, and the American, European, and Israelis' diplomats, not to mention their attempts to bomb cinemas, mosques, and malls. Thus, these contempt acts could be interpreted by Mannheim' social change theory. He believes that the basis of any conflict in any society is due to ideological, sectarian, and mental factors. Most of the social, political, and religious groups fight their opponents to take over the helm of the governance and to determine the policies of the state and its social system. Any emergence of a social change in any society is justified by the conflict between political, social, and religious rivals. In most cases, the dominant group controls the policies of the opponents and alters the progress of a society to serve their own purposes, interests, and objectives (Hassan, 2005).

\section{Terrorism's Definition}

Each society has a different perspective of terrorism's definition. In one society, a terrorist could be a man of virtue struggling for freedom. In other societies, he is considered as a criminal.

Terrorism has many different meanings. Sometimes, it is used to refer to the use of means that are capable of creating public danger or cause an imbalance in the public service of the community (Hussien, 1984). It can also mean using violence to achieve political goals or to establish a certain authority (Krini, 2002).

Yusuf (2006) defines terrorism as a means used: "to impose doctrines or religious opinions and thoughts on people with force and violence, instead of resorting to means of dialogue and cultural rights." It is the use of violence to achieve political objective, or the killing of innocent people by bandits (Michalak, 2002; Arcak, Bekci, Siyahhan \& Martinez, 2008).

Carr also defines terrorism as "warfare deliberately waged against civilians with the purpose of destroying their will to support either leaders or policies that the agents of such violence find objectionable" (cited in Goodwen, 2006).

Goodwen (2006) believes that terrorism is "the strategic use of violence and threats of violence by an oppositional political group against 
civilians or noncombatants, and is usually intended to influence several audiences."

Furthermore, Adeli (1993) defines terrorism as "the illegitimate use of power or violence against civilians or properties.” The acts of terrorism do not follow any morale assets. This is because they are linked with violence aimed at spreading terror and imposing an ideology by force. Also, it results in corruption, destruction, intimidation, and a creation of chaos in societies.

\section{Terrorism's Characteristics}

Terror acts have a common constitution that unites them as one regarding their characteristics. Thus, the characteristics of tourism include the following:

- $\quad$ Power is a major manifestation of terrorism, which refers to all acts of oppression and physical coercion that would harm individuals.

- $\quad$ Violence is the most irrational form in that it affects innocent victims who have no connection to terrorists or their opponents.

- $\quad$ Fear spreads panic and fright among innocent victims and causes severe mental disorders.

- Weapons: these include bombs and explosives that are easy to manufacture, and they do not require the presence of the terrorist at the moment of the explosion. Weapons should be easy to disassemble, transported, and smuggled via aircrafts that terrorists intend to hijack. Terrorist organizations give an enormous priority to collecting weapons and ammunitions that are easy to use and are not complicated.

- $\quad$ Confidentiality of planning and implementation.

- $\quad$ Media: terrorists respect all media to the extent that they resent being ignored by the media after any terror act. They even take initiation to contact the media and persist on presenting their concerns, ideas, and activities (Center of Information and Studies, 1993). In light of the previous characteristics, some political organizations in the Middle East countries have been classified as the most dangerous terrorist organizations. Consequently, this involves the Lebanese Hezbollah, the PKK, the Palestinian Hamas, Mujahedeen party of Iran, the Jewish party "Cash", the Algerian party "Jihad", ISIS, and Al-Qaeda, which includes multinational individuals.

\section{Terrorism's Types and Goals}

There are two types of terrorism that need to be differentiated. One type is called "selective terrorism" which is directed against noncombatants who are targeted because of their individual roles, such as politicians or state officials. The second type is called "categorical terrorism" which is the strategic use of violence and threats of violence by an oppositional political 
group against civilians or noncombatants. It is usually intended to influence several audiences who belong to specific ethnic, religious or national groups (Goodwen, 2006).

In most cases, terrorism seeks to destroy the morale of the opponents. It also aims at achieving political purposes, such as getting an access to ransom to finance their organizations. Furthermore, it also involves spreading their case as a matter of publicity through various media means. Mahdi (2004) expresses this idea as follows: "Although terrorists only want to kill few people, they want to be seen by a greater number of them."

Terrorists also aim at emphasizing the weakness of the government and showing how hopeless the government is in dealing with such vulnerable issues like state security. As a result, such organizations receive the public's sympathy. Thus, this facilitates the process of overthrowing the government's authority.

\section{Terrorism's Causes}

The causes of terrorism vary. Thus, there seem not to be a single factor that leads people to engage in acts of terror in many countries of the Arab world. As a result, scholars have categorized motivations for terrorism such as political, ideological psychological, economical, and educational.

\section{- $\quad$ Political Perspective}

The insecurity and instability of many states makes the presence of foreign bases to be one of its policies for maintaining security and stability. However, this trend of policy has received much debate among the terrorist groups. Also, it has become a motivation for further terrorist movements in countries such as Iraq and Pakistan (Mansouri, 2006).

- Ideological Perspective

Al-Yusuf (2006) noted that one of the main reason for terrorism in the Arab world lies behind the remarkably problematic issue of defining the concept of terrorism. There is a lack of objectivity in terrorism analysis which is usually analyzed politically. Even the debates of the seminars, or conferences on terrorism, is in conflict with each other in providing an acceptable definition. This definition is particularly due to the lack of accurate and objective data of terror acts. Even though there had been a consensus that terrorism was meant to "create fear in the soul", Arab sources do not clarify precisely who is a terrorist and what is terrorism. There is also a problem of addressing this phenomenon by only political or legal dimensions. Nevertheless, it should be approached and analyzed systematically and objectively from different dimensions (Hassan, 2000).

The misconception of religious texts of the holy books is another fundamental cause of terrorism. In most cases, the extreme terrorists believe that they had entered the circle of religion literacy if they had read the holy 
scripts and memorized them by heart. Terrorists can be bigoted about their religion or doctrine. Islamists, for instance, are a perfect example of the previous notion. They emphasize that their religion or doctrine is correct and all other doctrines are false. As a result, their duty is to impose their doctrine upon others either by force or power. Islamists are actually different from ordinary Muslims and true Islamic beliefs. Islamists believe that one must have political power and an Islamic state in order to practice Islam correctly; thus, they see a government dominated by Islamic law to be very necessary (Habeck, 2009).

\section{- $\quad$ Psychological Perspective}

Those who engage in terrorism may do so for purely personal reasons based on their psychological state of mind (United State Institute of Peace, 2001). Trauma, sense of humiliation and social exclusion, can all contribute to individuals joining terrorist organizations.

\section{- $\quad$ Economical Perspective}

Poverty and unemployment can motivate adults of poor Islamists families in countries that are experiencing political tensions to join organizations that commit terror acts under the belief that doing so is the only way to fulfill the spiritual duty of freeing their countries from conquerors (Gharaibeh, 2011; Van Hipple, 2002). Such acts are always sponsored generously by suicide financers who never hesitate to support and encourage terrorists to commit terror operations, or even suicide themselves. They even reassure them that their families will be taken care of, and that they will be well compensated after committing the required task (Vtevsrha Orehek, Fishman, Dechesnek, Chenk \& Krudlanski, 2009).

\section{- Educational Perspective}

Omoush (1999) noted that the terrorist acts in any society can also be affected by family disintegration, generational conflicts, and false methods of socialization. Not to mention, family stresses of religion can contribute effectively in the birth of a terrorist. False upraising methods such as poor social communication skills, denial, ignoring and humiliating offspring, and the absence of dialogue within the family may all help individuals, whether males or females, adopt the terrorist ideology. That is why a family should be balanced, modern, coexisting with reality, moderate in its religious beliefs, adapted to civilization and urbanization, living in peace with its community, accepting people the way they are, striving for love and affection, and praying for soft reform rather than war, violence, and roughness (Hussain, 2007). A society's educational systems can contribute to form a fertile environment for terrorists to find a secure shelter for their ideologies. This they do either by the authoritative methods of education or the recruitment of terrorists to work as teachers who in return look for new targets to recruit in their organizations. 
In addition, there should be enormous awareness by state's security, official governments, and families to monitor adults and immune them against terrorism. Young adolescents often yearn for new adventures and never hesitate to adopt odd thoughts without thinking about its consequences.

\section{Study's Objectives and Questions}

This research aims at investigating education college students' degree of awareness to terrorism's definition, type, main objective, and causes. This can be achieved by answering the following questions:

"What is terrorism", "What are the types of terrorism", "What is the main objective of terrorism? ", and "What are the real reasons for terrorism?"

\section{Significance of the Study}

This research is expected to shed lights on terrorism and raise the degree of awareness to its real goals and causes. In light of the study's results, the author would present suggestions to enhance university's roles in addressing it.

\section{Limitations of the Study}

The study's tool was implemented in Al al-Bayt University since the author works there. This, therefore, facilitated the gathering of the needed data by the author herself.

\section{Previous Studies}

Several studies were conducted to investigate terrorism's definition, goals, causes, and how to address it. In terms of terrorism's definitions, Michalak's (2002) research on what college students learn about terrorism, assumed that text books about terrorism provided sloppy definitions and an uncritical perpetuation of myths about it.

In terms of terrorism causes, Qader's (2001) research on the concept of international terrorism, assumes that terrorism seeks legitimacy from religion. Also, it points out the fact that many terrorists came from unprivileged backgrounds. Moghadam's (2005) study on the psychological processes leading to terrorism, assumes that "the terrorist's act is the final step on a narrowing staircase; although the vast majority of people, even when feeling deprived and unfairly treated, remain on the ground floor, some individuals climb up and are eventually recruited into terrorist organizations." However, these individuals believe they have no effective voice in the society. They are encouraged by leaders to displace aggression onto out-groups, and they became socialized to see terrorist organizations as legitimate and out-group members as evil. Al-Ghraibeh's (2011) research, terrorism and human rights in the Middle East, suggests that terrorism results 
from human development's absence, shortage of food, political conflicts, lack of education, and increasing poverty.

In terms of terrorism's types, kuipers' (2009) suggests that terrorist's acts are grouped into one of three main types which are: nationalists ideologically-based, or a hybrid of the two.

Moreover, related to terrorism goals, Foghen's (2006) reports on terrorism: actors-goals-targets-means, states six main goals for terrorism. These goals are ethno-nationalists, anti- colonial, secession-movement, social revolutionary movements, law and order movements against dictatorship, and religious motives.

Furthermore, the author believes that terrorism is a violent armed action against innocent people which is aimed at rebelling against government's policies and in achieving some religious gains.

\section{Method}

\section{Participants}

The size of the populations was 1197 (200 males, 997 females). Participants were comprised of 130 Jordanian undergraduate college students (16 males, 114 females) in their third (13.8\%) and forth year (86.2\%) which were selected randomly. In addition, these participants were studying at $\mathrm{Al}$ al Bayt University at the Department of Education. Also, they undertook the course (field training 2) during the scholastic year 2015-2016. Students' ages ranged from 20-35 $(M=22.21, S D=2.39)$.

\section{Procedures}

Surveys were administrated at the end of the first semester of the scholastic year 2015-2016. The survey required 10-15 minutes to complete. All participants accepted willingly to respond except 10 which were excluded from the sample.

\section{Instrument and Measures}

The data was collected by a 5-scale questionnaire which was designed by the author of this study. It was given to six professors at $\mathrm{Al}$-al Bayt University for validity purposes. According to their notes, one item was excluded and one domain was added (the educational domain with its five items), making the questionnaire in its final form consists of three sections. Firstly, students' personal information which includes sex, academic year, and age; secondly, three closed questions; and thirdly, 40 items distributed into five domains where five possible responses were provided to measure student's degree of conviction of the cause expressed in each item. The possible responses were very high $=5$, high $=4$, medium $=3$, low $=2$, very low $=1$. 
For reliability purposes, a pilot study was tested on 31 education college students undertaking the course Practical Education 1. This was before it was administrated to the actual participants. The external reliability coefficient for the total questionnaire domains was 0.84 , and the internal reliability coefficient (Cronbach Alpha) for the total questionnaire domains was 0.88 . Thus, this indicates that the questionnaire was reliable and suitable for a sample administration.

\section{Statistical Analysis}

Students' responses to multiple questions and items were analyzed using SPSS 14. Only descriptive statistics can be reported in this study due to the research questions. The author relied on the following statistical standard to judge the rank of each item regarding their means $(5-3.76=$ high, 3.66 $3.22=$ medium, less than $3.22-1=$ low).

\section{Results}

As mentioned earlier, due to research questions, only descriptive statistics can be reported in this study. When asked "what is the definition of terrorism?", students defined terrorism as the deliberate use of violence against civilians or vital bases of the state to achieve political, social, or religious targets" (49.2\%). It was followed by another definition; "the armed violence against innocent people" (26.9\%) (see Table 1).

Table 1. Students' responses to the question "What is Terrorism"

\begin{tabular}{ccc}
\hline What is terrorism? & Frequency & Percent \\
\hline $\begin{array}{c}\text { The deliberate use of violence against civilians or vital } \\
\text { bases of the state to achieve political, social, or } \\
\text { religious targets. }\end{array}$ & 64 & 49.2 \\
\hline \begin{tabular}{c} 
The armed violence against innocent people. \\
$\begin{array}{c}\text { The spread of terror and fear among the terrorists' } \\
\text { ideological and political opponents. }\end{array}$ \\
\hline Total
\end{tabular} & 31 & 26.9 \\
\hline
\end{tabular}

When asked "what is the type of the middle east terrorism?", 72.3\% of the students were convinced that terrorism is of the categorical type, whereas $27.7 \%$ of students believed that it is of the selective or individual type (see Table 2).

Table 2. Students 'responses to the question: "What is the Type of Middle East Terrorism?"

\begin{tabular}{ccc}
\hline What is the type of middle east terrorism? & Frequency & Percent \\
\hline Categorical Terrorism & 94 & 72.3 \\
Selective Terrorism & 36 & 27.7 \\
\hline Total & 130 & 100.0 \\
\hline
\end{tabular}

When asked "What is the main objective of terrorism?", $40.8 \%$ assumed that the main objective of terrorists' acts was to "earn a suitable 
ransom to finance the terror acts and organizations." $38.5 \%$ thought it was "to attract the media's attention to a specific case”, and 20.8\% thought it was to "get free from the foreign domination" (See Table 3).

Table 3. Students ' responses to the question: "What is the Main Objective of Terrorism?"

\begin{tabular}{ccc}
\hline What is the main objective of terrorism? & Frequency & Percent \\
\hline $\begin{array}{c}\text { Earn a suitable ransom to finance the terror acts and } \\
\text { organizations }\end{array}$ & 53 & 40.8 \\
$\begin{array}{c}\text { To attract the media' s attention to a specific case } \\
\text { Get free from the foreign domination }\end{array}$ & 50 & 38.5 \\
\hline Total & 27 & 20.8 \\
\hline
\end{tabular}

When students were asked "what are the real reasons for terrorism?", three domains out of five were highly estimated which were in the ascending order. They are: the economical domain $(M=3.97, S D=.77)$, the social domain $(M=3.89, S D=.62)$, and the educational domain $(M=3.85, S D=.60)$. Two domains out of five had medium estimations which were: the religious domain $(M=3.62, S D=.66)$ and the political domain $(M=3.58, S D=.68)$ (see Table 4).

Table 4. Descriptive statistics of the instruments' five domains

\begin{tabular}{cccc}
\hline SN & Domain & Mean & SD. \\
\hline 1 & Economical & 3.97 & .77 \\
2 & Social & 3.89 & .62 \\
3 & Educational & 3.85 & .60 \\
4 & Religious & 3.62 & .66 \\
5 & Political & 3.58 & .68 \\
\hline & Total & 3.76 & .48 \\
\hline
\end{tabular}

There were no low- ranked items as the items' means ranged between 4.37= high and 3.24= medium. Students thought that there were 19 causes of terrorism in the Middle East, as their means got the highest estimates in the ascending order: the unfruitful exploitation of youth energy (4.37), youth unemployment and the increase in poverty rates (4.24), prevalence of sins and evil (4.18), the loss of balance between the need of the labor market and the number of graduate students (4.15), the influence of bad company (4.09), the youth openness to the outside world without an appropriate guidance (4.08), being young (4.05), the misconception of holy scripts (4.02), less attention is given to the gifted or to the talented (4.02), the inefficiency of handling students' school drop (4.00), the lack of scientific role models (3.98), the absence of ethical oriented education (3.98), income inequality (3.95), schools' lack of interest in sports, music and art activities (3.89), the ease of access to terrorists' websites in internet cafes (3.85), education estrangement with critical thinking (3.85), poor distribution of economic wealth in one state (3.81), the absence of free dialogue platforms (3.78), and 
the spread of cultural illiteracy of terrorism among adults (3.77) (see Table 5).

Table 5. Descriptive statistics of students' responses to the question: "What are the real causes for terrorism?"

\begin{tabular}{|c|c|c|c|c|c|}
\hline SN & $\begin{array}{l}\text { Item } \\
\text { No. }\end{array}$ & What are the real causes for terrorism? & Mean & SD. & Rank \\
\hline \multicolumn{6}{|c|}{ Economical Domain } \\
\hline 1 & 31 & $\begin{array}{l}\text { Youth unemployment and the increase in } \\
\text { poverty rates }\end{array}$ & 4.24 & 1.07 & High \\
\hline 2 & 30 & $\begin{array}{l}\text { The loss of balance between the need of the } \\
\text { labor market and the number of graduate } \\
\text { students }\end{array}$ & 4.15 & 1.02 & High \\
\hline 3 & 28 & Income inequality & 3.95 & 1.10 & High \\
\hline 4 & 27 & $\begin{array}{l}\text { Poor distribution of economic wealth in one } \\
\text { state }\end{array}$ & 3.81 & 1.16 & High \\
\hline 5 & 29 & $\begin{array}{l}\text { Overcrowded slums due to migration from } \\
\text { the countryside to cities }\end{array}$ & 3.73 & 1.03 & Medium \\
\hline \multicolumn{6}{|c|}{ Social Domain } \\
\hline 6 & 15 & The unfruitful exploitation of youth energy & 4.37 & .92 & High \\
\hline 7 & 12 & The influence of bad company & 4.09 & 1.07 & High \\
\hline 8 & 10 & $\begin{array}{l}\text { The youth's openness to the outside world } \\
\text { without an appropriate guidance }\end{array}$ & 4.08 & 1.01 & High \\
\hline 9 & 17 & Being young. & 4.05 & .98 & High \\
\hline 10 & 14 & $\begin{array}{l}\text { The ease of access to terrorists' websites in } \\
\text { internet and social networks }\end{array}$ & 3.85 & 1.16 & High \\
\hline 11 & 13 & The absence of free dialogue platforms & 3.78 & 1.19 & High \\
\hline 12 & 18 & Delaying the age of marriage to thirty & 3.68 & 1.26 & Medium \\
\hline 13 & 11 & The sense of persecution and oppression & 3.68 & 1.15 & Medium \\
\hline 14 & 16 & The migration from countryside to city & 3.40 & 1.21 & Medium \\
\hline \multicolumn{6}{|c|}{ Educational Domain } \\
\hline 15 & 38 & $\begin{array}{l}\text { Less attention is given to the gifted or to } \\
\text { the talented }\end{array}$ & 4.02 & 1.09 & High \\
\hline 16 & 39 & $\begin{array}{l}\text { The inefficiency of handling students' } \\
\text { school drop }\end{array}$ & 4.00 & 1.04 & High \\
\hline 17 & 40 & The lack of scientific role models & 3.98 & 1.10 & High \\
\hline 18 & 33 & The absence of ethical oriented education & 3.98 & 1.06 & High \\
\hline 19 & 36 & $\begin{array}{c}\text { Schools' lack of interest in sports, music } \\
\text { and art activities }\end{array}$ & 3.89 & 1.04 & High \\
\hline 20 & 35 & $\begin{array}{c}\text { Education estrangement with critical } \\
\text { thinking }\end{array}$ & 3.85 & 1.08 & High \\
\hline 21 & 32 & $\begin{array}{l}\text { The spread of cultural illiteracy of } \\
\text { terrorism among adults }\end{array}$ & 3.77 & 1.13 & High \\
\hline 22 & 37 & $\begin{array}{l}\text { The absence of terrorism in universities } \\
\text { and schools curricula }\end{array}$ & 3.73 & 1.01 & Medium \\
\hline 23 & 34 & $\begin{array}{c}\text { The authoritative education of schools and } \\
\text { universities }\end{array}$ & 3.45 & 1.09 & Medium \\
\hline \multicolumn{6}{|c|}{ Religious Domain } \\
\hline 24 & 5 & Prevalence of sins and evil & 4.18 & 1.11 & High \\
\hline
\end{tabular}




\begin{tabular}{|c|c|c|c|c|c|}
\hline 25 & 3 & The misconception of holy scripts & 4.02 & 1.11 & High \\
\hline 26 & 9 & $\begin{array}{l}\text { Leaving the promotion of virtue and } \\
\text { forbidding the evil }\end{array}$ & 3.68 & 1.39 & Medium \\
\hline 27 & 1 & Religious or sectarian bigotry & 3.68 & 1.30 & Medium \\
\hline 28 & 2 & Religious extremism & 3.45 & 1.28 & Medium \\
\hline 29 & 8 & $\begin{array}{c}\text { Atonement to whom violates the terrorists } \\
\text { religion }\end{array}$ & 3.45 & 1.27 & Medium \\
\hline 30 & 4 & Linking religion to violence & 3.55 & 1.24 & Medium \\
\hline 31 & 6 & $\begin{array}{l}\text { The terrorist's conviction that his } \\
\text { repentance is not accepted }\end{array}$ & 3.36 & 1.06 & Medium \\
\hline 32 & 7 & $\begin{array}{l}\text { Instructions from religious figures } \\
\text { promoting for murder and terrorism }\end{array}$ & 3.24 & 1.40 & Medium \\
\hline \multicolumn{6}{|c|}{ Political Domain } \\
\hline 33 & 21 & $\begin{array}{c}\text { Developed countries' double standards } \\
\text { toward what is happening in the Middle } \\
\text { East }\end{array}$ & 3.68 & 0.98 & Medium \\
\hline 34 & 24 & $\begin{array}{l}\text { Oppressive style in confronting opponents' } \\
\text { political activities }\end{array}$ & 3.66 & 1.09 & Medium \\
\hline 35 & 23 & Low participation of youth in politics & 3.65 & 1.15 & Medium \\
\hline 36 & 25 & $\begin{array}{l}\text { The dictatorship governance that deprives } \\
\text { the political forces from participating in the } \\
\text { political change }\end{array}$ & 3.57 & 1.19 & Medium \\
\hline 37 & 26 & $\begin{array}{c}\text { Reliance on the security solution through } \\
\text { the harassment and torture of opponents, } \\
\text { which drives them to respond in armed } \\
\text { violence }\end{array}$ & 3.56 & 1.25 & Medium \\
\hline 38 & 20 & Lack of democratic practices & 3.55 & 1.01 & Medium \\
\hline 39 & 22 & $\begin{array}{l}\text { The absence of political pluralism which } \\
\text { allows real circulation of power }\end{array}$ & 3.48 & 1.05 & Medium \\
\hline 40 & 19 & $\begin{array}{c}\text { The experience of participating in the } \\
\text { Afghan war }\end{array}$ & 3.28 & 1.06 & Medium \\
\hline
\end{tabular}

\section{Discussion}

This study provides preliminary information about education college students' awareness to terrorism at the cognitive level. In general, most students seem to be fairly knowledgeable about terrorism. Students' responses show that their definition of terrorism is akin to the original definition of terrorism (see Yusuf, 2006; Goodwen, 2006). Students defined terrorism conceptually as "the deliberate use of violence against civilians or vital bases of the state to achieve political, social, or religious targets." This shows that students not only understand what terrorism means, but they can also differentiate it from other types of violent acts.

Students seem to have a clear vision about terrorism's types as they classified it as a categorical terrorism. This is because it is usually intended to influence several audiences who belong to specific ethnicity, religious or national groups. 
Ironically, the expected responses concerning the main objective of terrorism is expected to be either freeing the countries from foreign domination as in Iraq or rebelling against authoritarian regimes as Syria. However, students agreed to different unexpected objective for the terrorist acts in general. This is with the aim to get a financial ransom to support terrorists' organization due to the notion that terrorist organizations need to be well-armed. In addition, financing the recruitment of terrorists requires a grand budget that can only be earned by terrorists' acts.

This notion proved to be false by some researches (see Hipple, 2002). This is because most of the terror acts that had taken place recently in the Middle East, for example, were committed by middle-class terrorists, who yearned desperately to free their countries from the dictatorship domination. Not to mention, terrorists have a desperate need to draw public's attention and the international opinion to an important ideological issue through the media. However, this reveals a serious misconception by the college students to the real objectives of terrorism which needs further clarification.

Surprisingly, students thought that the main direct cause of terrorism is financial, as low incomes, the loss of balance between the need of the labor market and the number of graduate students, youth unemployment, the increase in poverty rates, and poor distribution of economic wealth in one state, could all contribute to the birth of a terrorist. Alan Kruger and Jitka Maleckova studied Israeli and Arab terrorism in the Middle East. Thus, their results demonstrated that terrorists enjoyed a living standard above the poverty line. They report that "any connection between poverty, education, and terrorism is indirectly complicated and is probably quite weak. It is more accurately viewed as a response to political conditions and long standing feelings of indignity and frustration that have little to do with economics" (cited in Hipple, 2002). Frankly, if a weak economy and poverty were the root cause of terrorism, terrorists would come from the poorest part of the world, which is not the case.

Students thought that social aspects could play vital roles in creating terrorism, particularly when there is a sense of oppression and persecution. Students believe that the youth are full of energy that has not been exploited perfectly. As a result, the youth have extra leisure time, which would assist in being recruited as a terrorist, specifically when they enjoy the terror acts, either as a reflection to the notion of sadism (see Gharaibeh, 2011), or as a manifestation of manhood.

Students also thought that in the absence of adequate monitoring of terrorists websites, there had been an ease of access to them. Therefore, this can contribute in one way or another to terrorism.

On the other hand, it is comforting to know that education college students are aware of the educational causes of terrorism and their 
significances in contributing to or preventing the creation of an environment for terrorism. Students believe that Middle East education is not an ethically oriented one. This is because it is still old-fashioned, and estranged from the critical thinking methods. Its methods of teaching are authoritative in both schools and universities. There is also a lack of interest in sports, arts, or musical activities since there is a strong conviction by some school principles and college instructors that such activities are a waste of time. This motivates some youth to drop school and join terrorists' organizations, specifically when they are feeling depressed because their needs are not satisfied and their talents or gifted abilities are not appreciated. Students are aware of an important issue concerning the adult's illiteracy to terrorism. It is considered as one of the forbidden topics to be discussed or to be talked about either in universities' or schools' curricula. This might explain the confused responses concerning the main objective of terrorism.

Students realized that some religious causes such as the prevalence of sins and evil, and the misconception of holy scripts, may contribute as well in the birth of terrorism in the Middle East. Nevertheless, it is not considered as the main direct cause of terrorism. This contradicts a strong conviction that the main cause of terrorism in the Middle East is Islam. This is because Islamists are the masterminds of terrorism. Therefore, this shows that students were convinced that terrorism has no religion and it is inappropriate to connect it to any religion, as God would never urge a man to kill innocent people for any cause.

Surprisingly, students thought that the political causes are the least cause of terrorism in the Middle East. If we take a look at what was and is still happening in some Middle East countries, such as Lebanon, Syria, Egypt and Iraq, the causes were confirmed to be either ideological or political. The dictatorship governance that deprives the political forces from participating in the political change can be a direct cause of terrorism. The lack of democratic practices is considered in some studies (see Dalacoura, 2006) to be a major cause of terrorism. Most of the terror acts that have taken place in the Middle East were committed by a terrorist who spent quiet a time in Afghanistan or had participated in its wars against the U.S forces. This reveals that students are not aware of the significance of the political and ideological causes which are actually the main causes of terrorism (Foghen, 2006).

In summary, Jordanian education college students are aware of terrorism' concept and type, but are less aware of terrorism's main objective and the significances of the political and ideological causes. 


\section{Author's Suggestions for Addressing Terrorism by Universities}

The author believes that fulfilling human needs rather than controlling people is the best way to create a secure social environment. Therefore, the best way to achieve that is by education. Universities represented by their students, faculties, and their communities should cooperate together in combating this phenomenon that is continually evident.

Addressing terrorism by universities can be achieved through two phases:

- $\quad$ First is prevention. The curricula that deal with the awareness of the concept of moderation in Islam is encouraged to be taught in universities and could be one of the university requirements that every college student should undertake in order to be able to get bright ideas and a real understanding of moderation in religion in the light of the world's great changes.

It involves embracing college students' problems and their whims, and bringing them closer to the adherence and laws of Islam without excess or negligence.

- $\quad$ The second phase includes rehabilitating those who are actually involved in terrorist groups. This is achieved through the improvement of their living and intellectual standards without addressing blame, censure or ostracism, and by reviewing models of repentant people of extremist ideas and how to exploit the religious faith they have in their religion to serve their country through advice and wisdom.

- Giving more attention to the members of the teaching staff at universities by holding seminars and conferences on terrorism and carrying out the activities that highlight the centrist image religion. Instructors should be encouraged to hold seminars and lectures on terrorism as they can play an influential role in the negotiation and the understanding of terrorism either inside or outside the classrooms. Thus, an understanding may enhance students' knowledge of terrorism and their roles in addressing it. This could be done by allocating a part of the lecture to talk about these issues and discuss its negative dimensions».

- A call for renewing the religious speech of religious curricula taught at universities which draw its origins from the true understanding of the holy scripts.

- $\quad$ Activating constructive dialogue and accepting others' thoughts and respecting his/her ideas in order to promote proper religious thoughts which focus on moderation and respecting others' opinions.

- $\quad$ The role of a true intellectual is in being a true leader of the state's institutions such as schools, media and universities, and not by excluding and considering him as a mere thinker. 


\section{Conclusion}

Students' misconception of terrorism's main objective and main causes, urges us as educators and researchers to illuminate them to the real objectives and motivations for terrorism. An analytical study of the resources which university students depend on, to seek information about terrorism, can further explain the students' misconception of the real causes of terrorism. These findings raise the questions of whether students' responses are a reflection of their alienation from their society or their refusal of the economic and social circumstances. The findings also raise the question of whether students understand fully the significances and roles of a society's ideology and its political conflicts in creating or preventing terrorism. Therefore, this study should be seen as a database for helping professionals to develop terrorism literacy programs for students, particularly for education college students.

\section{References:}

1. Adeli Mahmud (1993). Terrorism \& Punishment. Cairo: Arab Renaissance publishing Co., 64-66.

2. Aricak Tolga, Bekci Banu, Siyahan Sinem, \& Martinez Rebbecca (2008). Turkish Elementary School Students' Perception of Local and Global Terrorism. Education and Psychology, 6 (1), 117-134.

3. Center of Research and Information (1993). Terrorism: How to Face It \& How to Fight It. Cairo: The United Company for Publishing, 44.

4. Dalacoura Kathrina (2006). Islamist Terrorism and the Middle East Democratic Deficit: Political Exclusion, Repression and the Causes of Extremism. Democratization, 13(3), 508.

5. Foghen Jan (2006). Terrorism. Actors- Goals- Targets- Means. Cited from http://kkrva.se/wpcontent/uploads/Artiklar/061/kkrvaht_1_2006_6.pdf on 23-3-2016.

6. Garaibeh Fakir (2011). Human Security, Terrorism and Human rights in the Middle East: Implications for Social Work Practice. European Journal of Social Sciences, 20, 228.

7. Goodwen Jeff (2006). The Theory of Categorical Terrorism. Social Forces, 84( 4), 2027-2029

8. Habeck, M. (2009). Teaching the Long War and Jihadism. Foreign Policy Research Institute, 14, 1.

9. Hassan Ihsan (2008). The Sociology of Violence and Terrorism. Amman: Wa'el Publishing Co., 16-18.

10. Hassan Ihsan (2000). Karl Mannheim's Theory of Social Change. Journal of Social Sciences, 17, 1-6.

11. Hussien Ne'ma (1984). Global Terrorism. Beirut: Arab Union Studies' Center, 13. 
12. Kruglanski Arie, Chen Xiaoyan, Dechesne Mark, Fishman Shira, \& Orehek Edward. (2009). Fully Committed: Suicide Bombers' Motivation and the Quest for Personal Significance. Political Psychology, 30 (3), 331.

13. Krini Idrees (2002). Terrorism: Attempts \& History. Arabic Future Journal, 28, 37.

14. Kuiper, A., C. (2009). Cited from http://vanity.dss.ucdavis.edu/ maoz/International Paper.pdf, on 25-32016.

15. Mahdi Fekri (1993). The Explosives \& the Global Terrorism. Al Ma'ref Publishing Co., 30.

16. Mansouri Hameed (2006). The Controversy About Terrorism. Retrieved from www.siironline,.org on 21 December 2011.

17. Michalak Stanley (2002). What College Students Learn about Terrorism: A Case Study of IR Textbooks. Foreign Policy Research Institute, 7 (6).

18. Moghaddam Fm (2005). The Staircase to Terrorism: A Psychological Exploration. American Psychologist. 60, 2, 161-169, Feb. 1, ISSN: 0003-066X.

19. Omoush Ahmed (1999). Fighting Terrorism. Riyadh: Naïf Arab Academy for Security Sciences, 95-97.

20. Papp, D. (2002). Contemporary International Relations: Framework for Understanding ( $6^{\text {th }}$ edition). N.Y: Longman.

21. Rashwan Hussein (2002). Terrorism \& Extremism. College Youth Publishing Co., 37-56

22. United States Institution of Peace (2001). Teaching Guide on International Terrorism: Definitions, Causes, and Responses. Washington, DC, 10.

23. Von Hipple Karen (2002). The Roots of Terrorism: Probing the Myth. The Political Quarterly Publishing, 25-27.

24. Wright, J.D. (2015). A Social Identity and Social Power Perspective on Terrorism. Journal of Terrorism Research. 6(3), pp.76-83. DOI: http://doi.org/10.15664/jtr.1184

25. Yusuf Abdallah (2006). The Social Patterns and Roles in Fighting Terrorism and Extremism. Riyadh: Naïf Arab Academy for Security Sciences, 89-92.

\section{Appendix}

\section{Research' Questionnaire}

Dear students,

This questionnaire seeks to explore the degree of awareness of education college students of terrorism's definition, types, objectives, and 
causes at $\mathrm{Al}$ al- Bayt University. Kindly read the information provided in the questionnaire, and try to respond to it objectively. I confirm to you that all your responses will be dealt with confidentially, and will be used for merely scientific purposes.

\section{1- Personal information}

Sex: $\quad$ Male

Year:

First
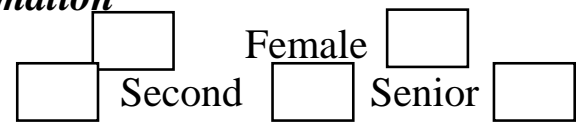

Graduate

Age:

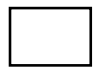

2- Kindly choose the adequate answer to the following questions:

\section{- What is terrorism?}

A): The deliberate use of violence against civilians or vital bases of the state to achieve political, social, or religious targets.

B): The armed violence against innocent people.

C): The spread of terror and fear among the terrorists' ideological and political opponents.

- What is the type of terrorism?
A): Categorical Terrorism
B): Selective Terrorism

\section{- What is the main objective of terrorism?}

- $\quad$ A): Earn a suitable ransom to finance the terror acts and organizations

- $\quad$ B): To attract the media' s attention to a specific case

- $\quad$ C): Get free from the foreign domination

3- Choose the adequate degree of conviction of Terrorism' causes implied in each item:

\begin{tabular}{|c|c|c|c|c|c|c|}
\hline \multirow[t]{2}{*}{ SN. } & \multirow[t]{2}{*}{ Item } & \multicolumn{5}{|c|}{ The Degree of Conviction } \\
\hline & & $\begin{array}{l}\text { Very } \\
\text { high }\end{array}$ & High & Medium & Low & $\begin{array}{l}\text { Very } \\
\text { low }\end{array}$ \\
\hline \multicolumn{7}{|c|}{ Religious Domain } \\
\hline 1 & Religious or sectarian bigotry & & & & & \\
\hline 2 & Religious extremism & & & & & \\
\hline 3 & The misconception of holy scripts & & & & & \\
\hline 4 & Linking religion to violence & & & & & \\
\hline 5 & The prevalence of sins and evil & & & & & \\
\hline 6 & $\begin{array}{l}\text { The terrorist's conviction that his } \\
\text { repentance is not accepted }\end{array}$ & & & & & \\
\hline 7 & $\begin{array}{l}\text { To have instructions from } \\
\text { religious figures promoting for } \\
\text { murder and terrorism }\end{array}$ & & & & & \\
\hline 8 & $\begin{array}{l}\text { Atonement to who violates the } \\
\text { terrorist's religion }\end{array}$ & & & & & \\
\hline 9 & $\begin{array}{l}\text { Leaving the promotion of Virtue } \\
\text { and forbidding evil }\end{array}$ & & & & & \\
\hline \multicolumn{7}{|c|}{ Social Domain } \\
\hline 10 & $\begin{array}{l}\text { The youth' openness to the outside } \\
\text { world without an appropriate }\end{array}$ & & & & & \\
\hline
\end{tabular}




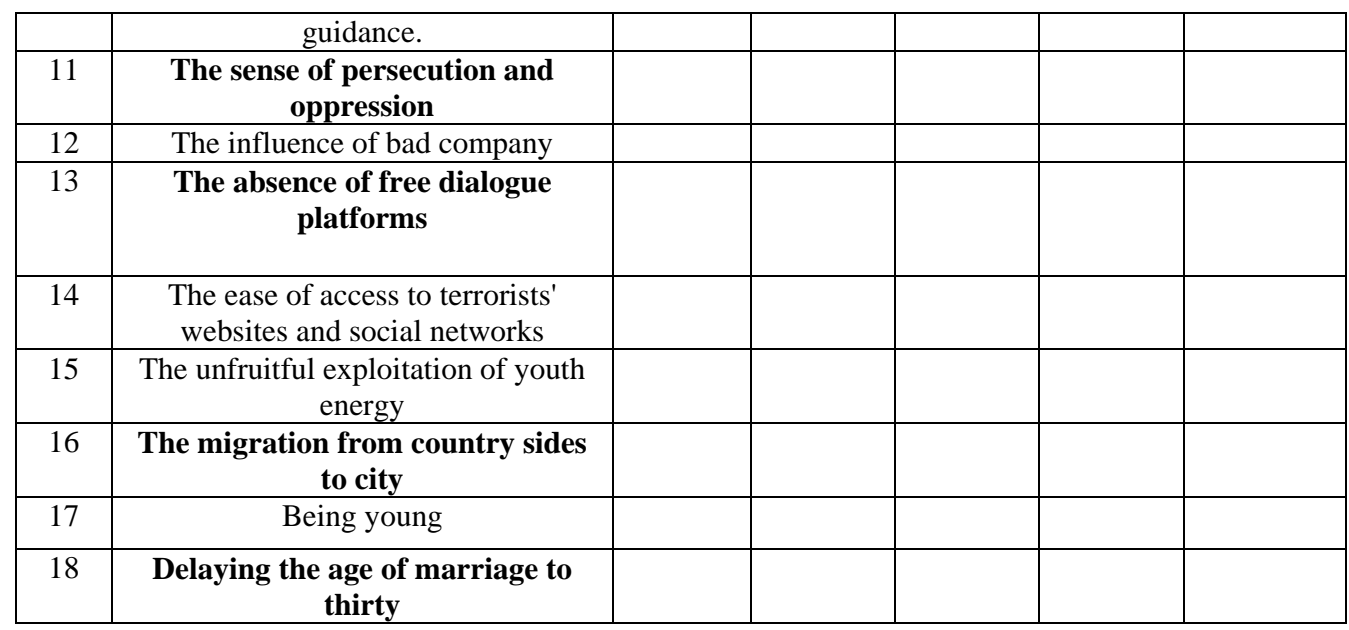

\begin{tabular}{|c|c|c|c|c|c|c|}
\hline \multirow[t]{2}{*}{ SN. } & \multirow[t]{2}{*}{ Item } & \multicolumn{5}{|c|}{ The Degree of Conviction } \\
\hline & & $\begin{array}{l}\text { Very } \\
\text { high }\end{array}$ & High & Medium & Low & Very low \\
\hline \multicolumn{7}{|c|}{ Political Domain } \\
\hline 19 & $\begin{array}{l}\text { The experience of participating in } \\
\text { the Afghan war }\end{array}$ & & & & & \\
\hline 20 & Lack of democratic practices & & & & & \\
\hline 21 & $\begin{array}{l}\text { Developed countries' double } \\
\text { standards toward what is } \\
\text { happening in the Middle East }\end{array}$ & & & & & \\
\hline 22 & $\begin{array}{c}\text { The absence of political pluralism } \\
\text { which allows real circulation of } \\
\text { power }\end{array}$ & & & & & \\
\hline 23 & $\begin{array}{l}\text { Low participation of youth in } \\
\text { politics }\end{array}$ & & & & & \\
\hline 24 & $\begin{array}{l}\text { Oppressive style in confronting } \\
\text { opponents' political activities }\end{array}$ & & & & & \\
\hline 25 & $\begin{array}{c}\text { The dictatorship governance that } \\
\text { deprives the political forces from } \\
\text { participating in the political } \\
\text { change }\end{array}$ & & & & & \\
\hline 26 & $\begin{array}{c}\text { The Reliance on the security } \\
\text { solution through the harassment } \\
\text { and torture of opponents, which } \\
\text { drives them to respond in armed } \\
\text { violence. }\end{array}$ & & & & & \\
\hline \multicolumn{7}{|c|}{ Economical Domain } \\
\hline 27 & $\begin{array}{l}\text { Poor distribution of economic } \\
\text { wealth in one state }\end{array}$ & & & & & \\
\hline 28 & Income inequality & & & & & \\
\hline 29 & $\begin{array}{l}\text { Overcrowded slums due to } \\
\text { migration from the country sides } \\
\text { to cities }\end{array}$ & & & & & \\
\hline 30 & $\begin{array}{l}\text { The loss of balance between the } \\
\text { need of the labor market and the } \\
\text { number of graduate students }\end{array}$ & & & & & \\
\hline
\end{tabular}




\begin{tabular}{|c|c|c|c|c|c|c|}
\hline \multirow[t]{2}{*}{ SN. } & \multirow[t]{2}{*}{ Item } & \multicolumn{5}{|c|}{ The Degree of Conviction } \\
\hline & & $\begin{array}{l}\text { Very } \\
\text { high }\end{array}$ & High & Medium & Low & Very low \\
\hline 31 & $\begin{array}{l}\text { Youth unemployment \& the } \\
\text { increase of poverty rates }\end{array}$ & & & & & \\
\hline \multicolumn{7}{|c|}{ Educational Domain } \\
\hline 32 & $\begin{array}{c}\text { The spread of cultural illiteracy of } \\
\text { Terrorism among adults }\end{array}$ & & & & & \\
\hline 33 & $\begin{array}{c}\text { The absence of ethical oriented } \\
\text { education }\end{array}$ & & & & & \\
\hline 34 & $\begin{array}{l}\text { The authoritative education of } \\
\text { schools and universities }\end{array}$ & & & & & \\
\hline 35 & $\begin{array}{l}\text { Education estrangement with } \\
\text { critical thinking }\end{array}$ & & & & & \\
\hline 36 & $\begin{array}{l}\text { Schools' lack of interest in sports, } \\
\text { music and art activities. }\end{array}$ & & & & & \\
\hline 37 & $\begin{array}{c}\text { The absence of terrorism in } \\
\text { universities and schools curricula }\end{array}$ & & & & & \\
\hline 38 & $\begin{array}{l}\text { Less attention is given to the gifted } \\
\text { or the talented }\end{array}$ & & & & & \\
\hline 39 & $\begin{array}{l}\text { The inefficiency of handling } \\
\text { students' school drop }\end{array}$ & & & & & \\
\hline 40 & The lack of scientific role models & & & & & \\
\hline
\end{tabular}

